\title{
IDENTIFIKASI TINGKAT RISIKO KAWASAN RENTAN BENCANA ALAM BANJIR SUNGAI KAYAN KABUPATEN BULUNGAN BERBASIS GEOGRAFIS INFORMASI SISTEM
}

\author{
Rachel Zandra Singal ${ }^{1}$, Noptri Jumario ${ }^{2}$ \\ ${ }^{1,2}$ Jurusan Teknik Sipil, Universitas Kaltara, Tanjung Selor 77212 \\ E-mail : jumario20@gmail.com
}

\begin{abstract}
ABSTRAK
Kabupaten Bulungan merupakan Daerah Aliran Sungai yang dialiri sungai utama yaitu Sungai Kayan dan sub-sub sungai lainnya, dan salah satu fungsi sungai ialah sebagai penampung alami aliran hujan jika musim penghujan tiba. Selain itu serangkaian bencana alam terjadi di wilayah Indonesia akibat dari perubahan iklim, Kabupaten Bulungan pun tak terhindar dari bencana banjir yang banyak menenggelamkan desa-desa yang berada di sepanjang sungai Kayan. Tujuan penelitian ini ialah untuk mengidentifikasi kawasan yang rentan terhadap banjir di Kabupaten Bulungan dan yang tervisualisasi dalam pera rentang bencana banjir. Penelitian ini menggunakan metode overlay dengan scoring antara parameter-parameter yang ada. Parameter yang digunakan untuk mengidentifikasi kerentanan terhadap banjir adalah curah hujan, kemiringan lereng dan ketinggian lahan. Selanjutnya setiap parameter dilakukan proses scoring dengan pemberian bobot dan nilai yang sesuai dengan pengklasifikasiannya masing-masing yang kemudian dilakukan overlay menggunakan software ArcGIS 10.5. Penggunaan software ini memanfaatkan Sistem Informasi Geografis (SIG) yang dapat menjelaskan dan menampilkan objek kawasan rentan banjir dalam bentuk digital. Hasil dari penelitian ini ialah teridentifikasinya tiga kawasan dengan katagori berbeda yaitu katagori tidak rentan yang berada pada Kecamatan Tanjung Palas, Tanjung palas; katagori rentan yang berada pada Kecamatan Tanjung Selor, Sekatak, Peso Hilir, Peso; katagori sangat rentan yaitu Kecamatan Tanjung Palas Tengah, dan Kecamatan Bunyu.
\end{abstract}

Kata Kunci: Kerentanan banjir, scoring, overlay, Kabupaten Bulungan

\section{PENDAHULUAN}

\subsection{Latar Belakang}

Bencana alam paling sering terjadi ialah banjir di antara bencana alam yang lain baik dilihat dari tingkat keseringannya pada suatu daerah maupun jumlah lokasi kejadian (Suherlan, 2001). Banjir merupakan peristiwa terjadinya genangan pada daerah datar sekitar sungai akibat meluapnya air sungai yang tidak mampu di tampung oleh sungai (Purnama. A, 2008).

Kabupaten Bulungan secara administrasi sebagai ibukota provinsi termudah yaitu Provinsi Kalimantan Utara, Kabupaten Bulungan juga merupakan Daerah Aliran Sungai yang beberapa tahun belakangan ini mengalami musibah banjir. Meluapnya sungai kayan dengan intensitas hujan yang tinggi, dan rentang banjir yang cukup lama yaitu lima sampai tujuh hari mengakibatkan kerugian ekonomi pada masyarakat di kota maupun di desa. Dampak banjir pada kawasan perkotaan pada umumnya adalah permukiman dan dampak banjir di pedesaan selain permukiman terendam banjir berdampak juga pada lahan pertanian, dan hewan ternak (Suhardiman, 2012).

Dalam upaya untuk mengantisipasi banjir tersebut, perlu adanya kajian mengenai kerentanan daerah yang sering terkena banjir dan juga mengetahui berapa besar besarnya curah hujan yang terjadi di kawasan - kawasan tersebut sehingga setiap tahunnya masyarakat dapat lebih mempersiapkan diri untuk menghadapi fenomena banjir ini. Pemetaan kawasan terdampak banjir dan juga pemetaan terhadap curah hujan di kabupaten Bulungan perlu dilakukan pemerintah agar dapat mengambil kebijakan yang tepat dalam menanggulangi banjir serta mengurangi kerugian yang dialami.

Berawal dari uraian tersebut dengan melalui Sistem Informasi Geografis diharapkan akan mempermudah penyajian informasi spasial khususnya yang terkait dengan penentuan tingkat kerentanan banjir serta dapat menganalisis dan memperoleh informasi baru dalam mengidentifikasi kawasan-kawasan yang sering menjadi sasaran banjir di Kabupaten Bulungan.

\subsection{Rumusan Masalah}

Berdasarkan latar belakang di atas, maka permasalahan yang coba diteliti ialah:

a) Berdasarkan parameter yang ada, apa parameter yang paling dominan terhadap penyebab banjir di Kabupaten Bulungan?

b) Bagaimana persebaran lokasi kawasan rentan banjir di Kabupaten Bulungan? 


\subsection{Tujuan Khusus Penelitian}

a) Memetakan kawasan rentan bencana banjir dengan SIG

b) Mengetahui tingkat kerentanan banjir berdasarkan parameter geografis dan hidrologis yang terjadi di Kabupaten Bulungan.

\section{METODE}

Metode yang digunakan pada pengolahan data penelitian ini menggunakan metode overlay dengan scoring antara parameter-parameter yang ada, yaitu kemiringan lereng, elevasi, jenis tanah, curah hujan, penggunaan lahan. Dari semua parameter ini nantinya akan di scoring dengan pemberian bobot dan nilai sesuai dengan pengklasifikasiannya masing-masing yang kemudian dilakukan overlay menggunakan software ArcGIS 10.5 (Matondang, J.P., 2013).

\subsection{Tahapan Penelitian}

Metode Penentuan Tingkat Rentan Banjir dalam penelitian ini meliputi tahapan langkah sebagai berikut :

a) Penentuan Bobot untuk masing-masing data parameter banjir

b) Penentuan Skor dengan perkalian antara bobot dan skor pada parameter banjir untuk mendapatkan urutan tingkatan pengaruh parameter

c) Klasifikasi parameter rentan banjir

d) Perhitungan penentuan Kerentanan Banjir

\subsection{Teknik Analisis Tingkat Kerawanan}

Untuk menentukan nilai dari parameter yang baru maka diperlukan suatu persamaan matematis dengan cara persamaan matematis dengan cara pembobotan yang telah dilakukan sebelumnya (Wismarini Dwiati, dkk. 2015). Persamaannya adalah :

$$
X=\sum_{i=1}^{n}(\mathrm{Wi} \times \mathrm{Wi})
$$

Rumus Tingkat Kerawanan Banjir

Keterangan:

$\mathrm{X}=$ Nilai kerawanan

$\mathrm{Wi}=$ Bobot untuk parameter ke-i

$\mathrm{Xi}=$ Skor kelas pada parameter ke- $\mathrm{i}$

Sehingga dari hasil persamaan tersebut kita bisa menentukan nilai standar untuk memberi skor pada peta yang baru. Dalam peta baru ini nilai skor ditentukan berdasarkan dimana wilayah dengan potensi banjir yang tinggi akan memiliki nilai yang tinggi. Tabel nilai untuk skor yang baru dapat dilihat pada tabel berikut.
Tabel 1. Skor Untuk Kerentanan Banjir

\begin{tabular}{ccc}
\hline No. & Kelas & Total Skor \\
\hline 1 & Tidak & $1,05-2,1$ \\
2 & Rentan & Rentan \\
$2,1-3,15$ \\
3 & $\begin{array}{c}\text { Sangan } \\
\text { Rentan }\end{array}$ & $3,16-4,2$ \\
\hline
\end{tabular}

Sumber: Sholahuddin (2015)

\section{HASIL DAN PEMBAHASAN}

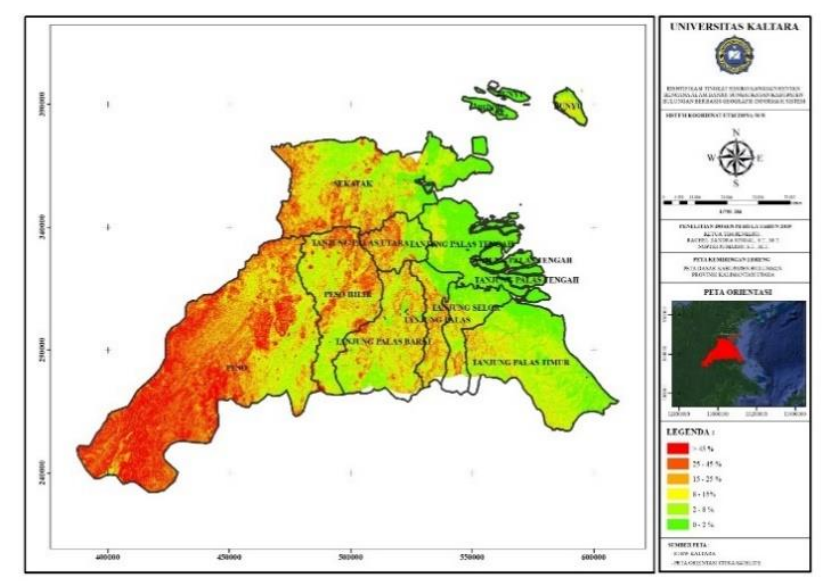

Gambar 1. Hasil klasifikasi kemiringan lereng

Tabel 2. Skor klasifikasi kemiringan lereng

\begin{tabular}{llrrr}
\hline \multicolumn{1}{c}{$\underline{\underline{0}}$} & \multicolumn{1}{c}{ Deskripsi } & Nilai & Bobot & \multicolumn{1}{c}{ Skor } \\
\hline $0-8$ & Datar & 5 & 0,2 & 1 \\
$8-15$ & Landai & 4 & 0,2 & 0,8 \\
$15-25$ & Agak Cram & 3 & 0,2 & 0,6 \\
$25-45$ & Curam & 2 & 0,2 & 0,4 \\
$45-100$ & Sangat Curam & 1 & 0,2 & 0,2 \\
\hline
\end{tabular}

Berdasarkan gambar 1. bagian hilir Sungai Kayan di Kabupaten Bulungan mempunyai kemiringan lereng yang di dominasi datar dan landai dalam persentase kemiringan 0 - $15 \%$ yaitu Kecamatan Tanjung Selor, Tanjung Palas, bahkan Tanjung Palas Timur berkategori landai. Hal ini sangat berpotensi terjadi banjir karena wilayah ini cenderung datar yang bisa menjadi daerah tampungan air ketika hujan. Sedangkan daerah yang memiliki wilayah curam berada di Kabupaten Bulungan bagian hulu Sungai Kayan seperti pada sebagian besar Daerah Kecamatan Peso yang mempunyai persentase kemiringan $25-45 \%$ sehingga daerah ini bisa di kategorikan sangat aman dari bencana banjir. Walaupun Kecamatan Peso juga terendam banji pada 4 (empat) tahun belakang ini. Hal ini dikarenakan tidak seluruhnya Kecamatan Peso memiliki kategori kelerengan $45 \%$ di peta menunjukkan bahwa ada sebagian wilayah Kecamatan Peso memiliki kelerengan $0-8 \%$ yang artinya terkategori datar dan landai ini yang menyebabkan Kecamatan Peso ikut terdampak banjir pada musim penghujan. 


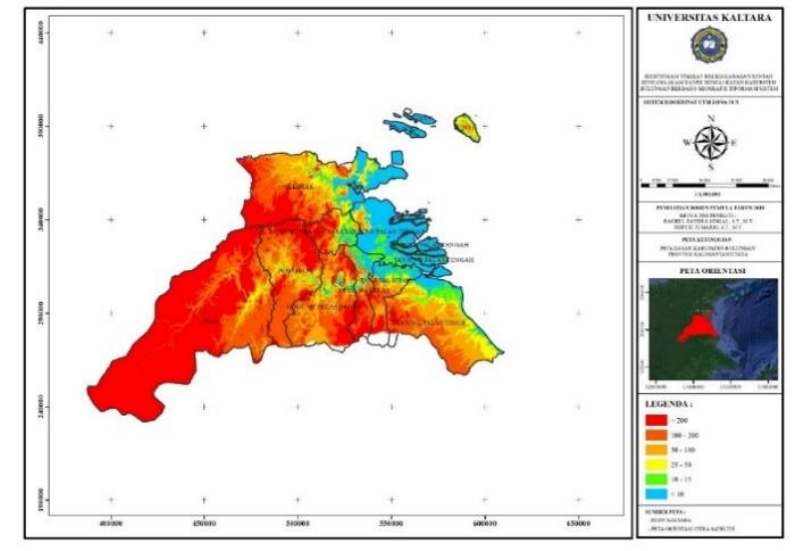

Gambar 2. Hasil klasifikasi kemiringan lereng

Tabel 3. Skor klasifikasi kemiringan lereng

\begin{tabular}{lrrr}
\hline Elevasi & Nilai & Bobot & \multicolumn{1}{c}{ Skor } \\
\hline$<10$ & 5 & 0,35 & 1,75 \\
$10-15$ & 4 & 0,35 & 1,4 \\
$50-100$ & 3 & 0,35 & 1,05 \\
$100-200$ & 2 & 0,35 & 0,7 \\
$>200$ & 1 & 0,35 & 0,35 \\
\hline
\end{tabular}

Berdasarkan gambar 2. menunjukkan bahwa yang terkategori mempunyai elevasi kurang dari 10 meter di atas permukaan air laut itu tersebar di Kecamatan Bunyu, Tanjung Selor, Tanjung Palas, dan Tanjung Palas Tengah. Hal ini sangat berpotensi terjadi banjir karena semakin rendah elevasi suatu daerah, semakin rawan pula daerah tersebut untuk terjadi banjir, begitu pula sebaliknya. Namun tidak hanya bagian utara dan timur saja yang mempunyai elevasi sangat rendah, misalnya pada sebagian kecil Kecamatan Tanjung Palas Barat, dan Tanjung Palas Utara juga mempunyai elevasi sangat rendah yaitu kurang dari 10 meter di atas permukaan air laut. Sedangkan daerah yang mempunyai elevasi tinggi terletak pada sebagian besar Kecamatan Peso Kecamatan Peso Hilir, Kecamatan Sekatak, dan Kecamatan Tanjung Palas Barat dengan ketinggian antara 100 - > 200 meter di atas permukaan laut.

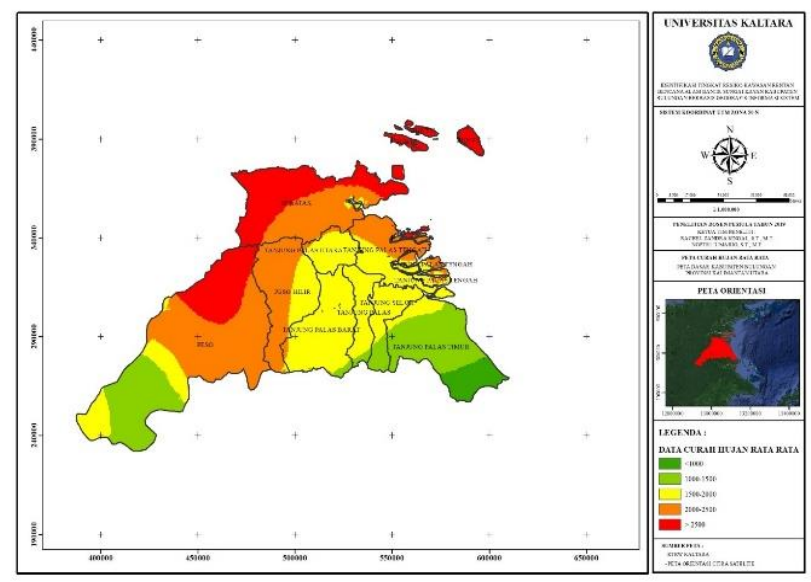

Gambar 3. Hasil klasifikasi curah hujan
Tabel 4. Skor klasifikasi kemiringan lereng

\begin{tabular}{lcccc}
\hline \multicolumn{1}{c}{ Kelas } & Deskripsi & Nilai & Bobot & Skor \\
\hline$>2500$ & Sangat Basah & 5 & 0,4 & 2 \\
$2001-2500$ & Basah & 4 & 0,4 & 1,6 \\
$1501-2000$ & Sedang & 3 & 0,4 & 1,2 \\
$1000-1500$ & Ringan & 2 & 0,4 & 0,8 \\
$<1000$ & Sangat Ringan & 1 & 0,4 & 0,4 \\
\hline
\end{tabular}

Berdasarkan hasil klasifikasi curah hujan rata - rata tahun 2016 Kabupaten Bulungan hasil Poligon Thiessen bersumber dari BAPPEDA tahun 2016, rata-rata curah hujan tahunan Kabupaten Bulungan adalah 2000 - 2500 $\mathrm{mm} /$ tahun yang tergolong dalam kategori basah. Curah hujan dengan katagori sangat basah dan basah berada di sebagian Kecamatan Peso, Kecamatan Sekatak, sedangkan wilayah Kecamatan Bunyu katagori sangat basah. Katagori sedang dan basah berada di Kecamatan Peso Hilir, Kecamatan Tanjung Palas Tengah katagori sedang berada di Kecamatan Tanjung Palas Barat, Tanjung Selor, Tanjung Palas, Tanjung Palas Utara. Berbeda dengan Kecamatan Tanjung Palas Timur dengan katagori ringan dan sangat ringan.

Berdasarkan parameter dan bobot yang sudah ditentukan dalam penelitian ini, maka parameter curah hujan dengan bobot 0,40 menjadi parameter yang paling dominan terhadap terjadinya banjir dimana $>2500 \mathrm{~mm} /$ tahun pada tahun 2016 dengan katagori sangat basah berada di Kecamatan Sekatak dan sebagian di Kecamatan Peso, Kemudian Parameter yang berpengaruh selanjutnya yaitu ketinggian lahan dengan bobot 0,35, dimana elevasi terendah memiliki skor paling tinggi yang berada di Kecamatan Sekatak dengan elevasi kurang dari $<10$ meter di atas permukaan air laut. Dan parameter terakhir yang dominan yaitu parameter kemiringan lereng dengan bobot 0,20 . Untuk lebih jelas dapat dilihat pada tabel penskoran dari parameter di bawah ini.

Tabel 5. Hasil Penskoran Klasifikasi Kelerengan Klasifikasi Kelerengan

\begin{tabular}{lccc}
\hline Deskripsi & Nilai & Bobot & Skor \\
Datar & 5 & 0,20 & 1,00 \\
Curam & 2 & 0,20 & 0,40 \\
Datar & 5 & 0,20 & 1,00 \\
Landai & 4 & 0,20 & 0,80 \\
Sangat curam & 1 & 0,20 & 0,20 \\
Curam & 2 & 0,20 & 0,40 \\
Curam & 2 & 0,20 & 0,40 \\
Datar & 5 & 0,20 & 1,00 \\
Landai & 4 & 0,20 & 0,80 \\
Sangat curam & 1 & 0,20 & 0,20 \\
\hline
\end{tabular}


Tabel 6. Hasil Penskoran Klasifikasi Ketinggian

\begin{tabular}{lccc}
\hline \multicolumn{4}{c}{ Klasifikasi Ketinggian } \\
\hline \multicolumn{1}{c}{ Elevasi } & Nilai & Bobot & Skor \\
$100-200$ & 2 & 0,35 & 0,70 \\
$10-15$ & 1 & 0,35 & 0,35 \\
$<10$ & 5 & 0,35 & 1,75 \\
$100-200$ & 2 & 0,35 & 0,70 \\
$>200$ & 1 & 0,35 & 0,35 \\
$>201$ & 1 & 0,35 & 0,35 \\
$>200$ & 1 & 0,35 & 0,35 \\
$<10$ & 5 & 0,35 & 1,75 \\
$>200$ & 1 & 0,35 & 0,35 \\
$>200$ & 1 & 0,35 & 0,35 \\
\hline
\end{tabular}

Tabel 7. Hasil Penskoran Klasifikasi Curah Hujan Klasifikasi Curah Hujan

\begin{tabular}{lccc}
\hline \multicolumn{1}{c}{ Deskripsi } & Nilai & Bobot & Skor \\
Sedang & 3 & 0,4 & 1,2 \\
Sedang & 3 & 0,4 & 1,2 \\
Sedang & 3 & 0,4 & 1,2 \\
Sangat & 1 & 0,4 & 0,4 \\
ringan & & & \\
Sedang & 3 & 0,4 & 1,2 \\
Sedang & 3 & 0,4 & 1,2 \\
Sangat basah & 5 & 0,4 & 2 \\
Sangat basah & 5 & 0,4 & 2 \\
Basah & 4 & 0,4 & 1,6 \\
Sangat basah & 5 & 0,4 & 2 \\
\hline
\end{tabular}

Tabel 8. Hasil Jumlah Penskoran Kawasan Rentan Bencana Banjir di Kabupaten Bulungan

\begin{tabular}{lcc}
\hline \multicolumn{1}{c}{ Kecamatan } & $\begin{array}{c}\text { Jumlah } \\
\text { Skor }\end{array}$ & $\begin{array}{c}\text { Tingkat } \\
\text { Kerawanan }\end{array}$ \\
\hline Tanjung Selor & 2,90 & Rentan \\
Tanjung Palas & 1,95 & Tidak Rentan \\
Tanjung Palas & & Sangat Rentan \\
Tengah & 3,95 & \\
Tanjung Palas & & Tidak Rentan \\
Timur & 1,90 & \\
Tanjung Palas & & Tidak Rentan \\
Utara & 1,75 & \\
Tanjung Palas & & Tidak Rentan \\
Barat & 1,95 & Rentan \\
Sekatak & 2,75 & Sangat Rentan \\
Bunyu & 4,75 & Rentan \\
Peso Hilir & 2,75 & Rentan \\
Peso & 2,55 & \\
\hline
\end{tabular}

Berdasarkan Tabel 8, tentang hasil penskoran kawasan rentan bencana banjir Kabupaten Bulungan dengan 10 (sepuluh) Kecamatan, yaitu di, Tanjung Selor, Tanjung Palas, Tanjung Palas Tengah, Tanjung Palas Timur, Tanjung Palas Utara, Tanjung Palas Barat, Sekatak, Bunyu, Peso Hilir, dan Peso, maka ada tiga kategori bencana banjir yaitu tidak rentan, rentan dan sangat rentan bencana banjir. Lebih jelasnya dapat di lihat pada peta hasil overlay dari parameter yang ditentukan.

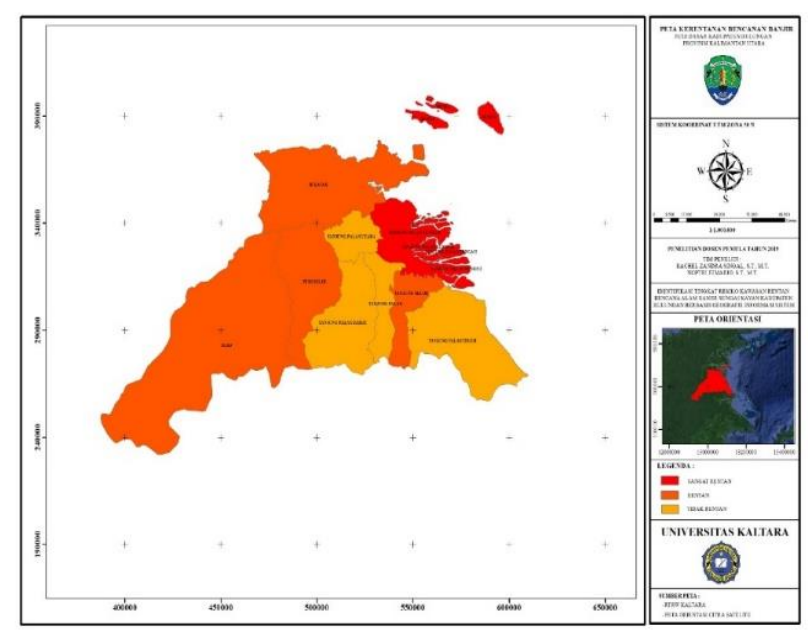

Gambar 4. Hasil klasifikasi curah hujan

Wilayah yang mempunyai kategori tidak rentan adalah wilayah Kecamatan Tanjung Palas, Kecamatan Tanjung Palas Timur, Tanjung Palas Utara, Tanjung Palas Barat. Wilayah ini mendapatkan katagori tidak rentan karena memiliki jumlah skor dengan reng 1,05 - 2,1. Pada Tabel 5 menunjukkan bahwa Kecamatan Tanjung Palas, Tanjung Palas Barat memiliki kelerengan curam, dan Kecamatan Tanjung Palas Utara memiliki kelerengan sangat curam, berbeda dengan Tanjung Palas Timur yang memiliki kelerengan landai, walaupun demikian Kecamatan tanjung Palas di dukung dengan parameter curah hujan rata - rata tahunan yang sangat ringan, hal ini dikarenakan parameter curah hujan rata - rata tahunan adalah parameter dominan sehingga Kecamatan Tanjung Palas Timur Memiliki Katagori tidak rentang.

Kemudian wilayah yang mendapat katagori rentan adalah Kecamatan Tanjung selor, Sekatak, Peso Hilir, dan Peso yang memiliki jumlah skor dengan reng 2,1-3,15. Hal ini di sebabkan karena, Kecamatan Tanjung Selor memiliki kelerengan datar dengan elevasi berkisar $100-200$ meter di atas permukaan laut, dan curah hujan sedang. Dari parameter kelerengan Kecamatan Peso mempunyai kelerengan sangat curam, lalu Kecamatan Sekatak katagori curam dengan parameter curah hujan dengan katagori sangat basah, yang berbeda dengan Kecamatan Peso Hilir mempunyai katagori landai dengan curah hujan katagori basah., hal ini yang menyebabkan Kecamatan Sekatak, Kecamatan Peso, Peso Hilir, dan Kecamatan Tanjung Selor memiliki katagori rentan banjir. 
Selanjutnya, wilayah yang mendapat katagori sangat rentan ialah Kecamatan Tanjung Palas Tengah, dan Kecamatan Bunyu yang memiliki jumlah skor terbanyak yaitu antara 3,16 - 4,2. Kedua Kecamatan ini memiliki skor parameter kelerengan dan parameter elevasi yang sama yaitu datar dan ketinggian di bawah $<10$ meter di atas permukaan air laut, sedangkan skor parameter curah hujan rata-rata tahunan yang berbeda tipis, yaitu katagori sedang ada pada Kecamatan Tanjung Palas Tengan sedangkan Kecamatan Bunyu berkategori sangat basah dengan jumlah skor tertinggi yaitu 4,75 .

\section{KESIMPULAN DAN SARAN}

Berdasarkan hasil dan pembahasan penelitian di atas, maka dapat di tarik kesimpulan dan saran sebagai berikut :

1. Kabupaten Bulungan memiliki 3 (tiga) kategori tingkat kerentanan banjir. Pertama katagori tidak rentan yang berada pada Kecamatan Tanjung Palas, Tanjung palas Timur, Tanjung Palas Utara, Tanjung Palas Barat. Kedua Katagori rentan yang berada pada Kecamatan Tanjung Selor, Sekatak, Peso Hilir, Peso. Ketiga Katagori sangat rentan yaitu Kecamatan Tanjung Palas Tengah, dan Kecamatan Bunyu.

2. Parameter dominan terhadap banjir adalah Parameter curah hujan rata - rata data tahun 2016, selanjutnya parameter ketinggian lahan/elevasi, dan diikuti kemiringan lereng.

3. Sebaran lokasi kawasan rentan banjir tersebar di seluruh Kecamatan di Kabupaten Bulungan, dengan tingkatan kerentanan yang berbeda.

\section{UCAPAN TERIMA KASIH}

Penulis mengucapkan terima kasih kepada Direktorat Riset dan Pengabdian Masyarakat Direktorat Jenderal Penguatan Riset dan Pengembangan Kementerian Riset, Teknologi, dan Pendidikan Tinggi atas anggaran dana penelitian hibah RISTEKDIKTI sesuai surat perjanjian pelaksanaan penelitian nomor: SK/7/E/KPT/2019 tanggal 8 April 2019. Penulis juga mengucapkan terima kasih kepada semua pihak yang membantu dalam penelitian ini.

\section{DAFTAR PUSTAKA}

[1] Suherlan, 2001. Zonasi Tingkat Kerentangan Banjir Kabupaten Bandung Menggunakan Sistem Informasi Geografis. Bogor.

[2] Wismarini Dwiati, dkk. 2015. Penentuan Tingkat Kerentanan Banjir Secara Geospasial. Jurnal Teknologi Informasi DINAMIK. Universitas Stikubank Semarang.

[3] Matondang, J.P., 2013. Analisis Zonasi Daerah Rentan Banjir Dengan Pemanfaatan Sistem Informasi Geografis. Universitas Diponegoro. Semarang.

[4] Sholahuddin, Muhamad. 2015. "SIG Untuk Memetakan Daerah Banjir Dengan Metode Skoring dan Pembobotan (Studi Kasus Kabupaten Jepara).

[5] Purnama, A. 2008. Pemetaan Kawasan Rawan Banjir di Daerah Aliran Sungai Cisadane Menggunakan Sistem Informasi Geografis. Institut Pertanian Bogor.

[6] Suhardiman, 2012. Zonasi Tingkat Kerawanan Banjir dengan Sistem Informasi Geografis (SIG) pada Sub DAS Walanae Hilir. Universitas Hasanuddin Makassar. 